\title{
Early Yield Testing and Selection of Upland Rice on Observational Study in Kebumen, Central Java
}

\author{
Uji Daya Hasil dan Seleksi Padi Gogo pada Penelitian Observasi \\ di Kebumen, Jawa Tengah
}

\author{
Angelita Puji Lestari ${ }^{1}$, Aris Hairmansis ${ }^{1}$, Rini Hermanasari ${ }^{1}$, Yullianida ${ }^{1}$, and Suwarno ${ }^{1}$ \\ ${ }^{1}$ Indonesian Center for Rice Research (ICRR) Jl. Raya 12 Sukamandi Subang \\ 41256 West Java Telp./fax: (0260)520157/(0260)520158
}

\begin{abstract}
The use of upland rice variety is an effort to expand rice cultivation to dry land due to the decreasing of fertile land in Indonesia. In order to develop a high yielding rice line, a primary population with high genetic diversity is needed in character related to grain yield. This experiment aimed to study the genetic variability of some important characters of upland rice lines as primary data for the selected program. The research was carried out in the farmland of Mirit Village, Kebumen, Central Java. The genetic material consisted of 203 new promising lines and five varieties as a check, namely Inpago 6, Inpago 8, Limboto, Situpatenggang, and Situbagendit. This observation yield trial used an augmented design with five replicates of the check varieties, with a spacing of $30 \mathrm{x}$ $15 \mathrm{~cm}$. The data analysis showed that the rice lines, line vs. check, and block were significantly different in the number of productive tillers. The significant effects of lines with the check varieties were in plant height, flowering age, harvest age, and a number of productive tillers. The number of productive tillers had wide genetic variation, broad sense heritability, and high genetic gain so that it can be utilized as selection criteria. Twelve lines were identified as a higher number of productive tillers, and three lines had a higher yield compared to the best varieties of Situbagendit, based on Least Significant Increase (LSI) test.
\end{abstract}

Keywords: upland rice, selection, genetic parameter, observation

\begin{abstract}
Abstrak: Penggunaan varietas padi gogo merupakan upaya perluasan pertanaman padi ke arah lahan kering yang disebabkan semakin berkurangnya lahan subur di Indonesia. Untuk menyusun program pemuliaan padi gogo berdaya hasil tinggi, diperlukan populasi dasar dengan keragaman genetik yang tinggi pada karakter yang berkaitan dengan daya hasil tanaman. Tujuan penelitian ini adalah mempelajari keragaan dan keragaman genetik beberapa karakter penting galur-galur harapan padi gogo yang digunakan sebagai data program seleksi. Penelitian dilaksanakan di lahan petani Desa Mirit, Kebumen Jawa Tengah. Material genetik yang diuji terdiri dari 203 galur dan lima varietas sebagai pembanding, yaitu Inpago 6, Inpago 8, Limboto, Situpatenggang, dan Situbagendit. Percobaan observasi menggunakan rancangan augmented dengan lima ulangan terhadap varietas pembandingnya, dengan jarak tanam $30 \times 15 \mathrm{~cm}$. Analisis data menunjukkan galur-galur padi gogo, galur vs cek, dan blok berbeda nyata pada karakter jumlah anakan produktif. Pengaruh nyata antara galur dengan varietas pembanding terdapat pada karakter tinggi tanaman, umur berbunga, umur panen, dan jumlah anakan produktif. Karakter jumlah anakan produktif memiliki ragam genetik luas, nilai heritabilitas, serta kemajuan genetik yang tinggi sehingga dapat dimanfaatkan sebagai kriteria seleksi. Teridentifikasi 12 galur dengan jumlah anakan produktif lebih tinggi dan 3 galur dengan hasil lebih tinggi dibandingkan varietas pembanding terbaik Situbagendit, berdasarkan uji Least Significant Increase (LSI).
\end{abstract}

Kata kunci: padi gogo, seleksi, parameter genetik, observasi

\section{Introduction}

Conversion of agricultural land for rice cultivation, in particular, leads to a reduction in the fertile area from year to year. This condition causes the importance of expanding the area with the use of dry land in the lowlands and highlands. Dryland has the potential to support increasing rice production. Abdurrachman et al. (2008) suggested that Indonesia has approximately 148 
million ha of dry land, but which can be utilized for agricultural cultivation is only 76.22 million ha $(52 \%)$ andmostly in the lowlands of 70.71 million ha (93\%). However, the productivity of rice in marginal or suboptimal is still low at about $2 \mathrm{t} /$ ha compared to the average national rice productivity, which reached 4.98 t/ha (BPS, 2013). Also, the contribution of suboptimal land to national rice production is still low or only about $5-6 \%$.

The main focus of the upland rice breeding program is to develop high-yielding rice varieties, high tolerance to specific biotic and abiotic stresses, and good quality rice. Upland rice varieties that have been released have certain advantages but still, have some weaknesses. Research on the assembly of abiotic tolerant strains of upland rice, such as aluminum tolerant (Herawati et al. 2010) and shade tolerance (Sasmita 2007) has been done for the development of upland rice in sub-optimal environments. However, the development of high yielding varieties has to do through genetic variation, and it is governing the inheritance of quantitative characteristics, yield, and yield component. The understanding of genetic variability is imperative for the success of any plant breeding program. The parameters such as genotypic and phenotypic coefficients of variation (GCV and $\mathrm{PCV}$ ) are useful in detecting the amount of variability present in a given characteristic. Heritability of a character is essential in determining its response to selection. Genetic improvement of plants for quantitative traits requires reliable estimates of heritability in order to plan an efficient breeding program (Perera et al. 2014). Heritability, coupled with high genetic gain $(G)$ would be more useful in predicting the resultant effect in the selection of the best genotypes for yield and its attributing traits (Ogunniyan and Olakojo 2014).

Plant breeding program for assembling a variety started by determining of the breeding objective, collecting breeding materials, characterizing of collections, making genetic recombination, then selection following by evaluation and testing. Selection based on quantitative analysis data which is guided by the value of heritability, genotypic diversity, and phenotype guidance to obtain better results. With the existence of extensive genetic diversity will be obtained flexibility in the selection of superior genotypes or improvement of traits (Saleem et al., 2008). The observational experiments used in this experiment consisted of several advancedgeneration lines beginning with $\mathrm{F} 6-\mathrm{F} 7$ generations. Further experimental yield trial results start from preliminary and advanced yield trial. The purpose of this experiment is to study the genetic variability and diversity of some famous characters of promising upland rice lines.

\section{Materials and Method}

The experiments of the upland rice lines were carried out in Kebumen on Planting Season 12017 started from September to December 2017. The materials used in this experiment were about 203 lines of upland rice from the ICRR breeding program and five varieties of Inpago 6, Inpago 8, Limboto, Situpatenggang, and Situbagendit. The experiment was arranged in augmented design with five replicates of its check varieties, with a spacing of $30 \mathrm{x}$ $15 \mathrm{~cm}$. Each line was planted in a plot size of $1 \mathrm{~m} \mathrm{x} 5$ $\mathrm{m}$ and spacing of $30 \mathrm{~cm} \times 15 \mathrm{~cm}$. Fertilization used were $300 \mathrm{~kg}$ NPK (Phonska) + $100 \mathrm{~kg}$ Urea/ha. Weeding was done twice that at the time of fertilization follow-up I and II. Traits observed were $50 \%$ flowering age, harvest age, plant height, number of productive tillers, and yield.

Analysis of variance was calculated using Microsoft Excel and SAS v9.1 software. The genetic parameters were calculated based on the separation of the mean square (Table 1$)$. Genotypic variance $\left(\sigma^{2} \mathrm{~g}\right)$, phenotypic variance $\left(\sigma^{2} \mathrm{p}\right)$, genotypic coefficient of variation (GCV \%), phenotypic coefficient of variation (PCV \%), heritability (hbs) and Genetic gain $(\mathrm{G})$ were estimated by the formula suggested by Johnson et al. (1955) and Singh and Chaudary (1979).

Table 1 Analysis of variance for augmented design

\begin{tabular}{lllll}
\hline Variance & $\mathbf{d b}$ & $\begin{array}{l}\text { Sum } \\
\text { square }\end{array}$ & $\begin{array}{l}\text { Mean } \\
\text { square }\end{array}$ & $\begin{array}{l}\text { Mean } \\
\text { square } \\
\text { est. }\end{array}$ \\
\hline Block $(\mathrm{r})$ & $\mathrm{r}-1$ & $\mathrm{SSb}$ & $\mathrm{MSb}$ & \\
Genotype & $(\mathrm{l}+\mathrm{c})-1$ & $\mathrm{SSg}$ & $\mathrm{MSg}$ & \\
Line $(\mathrm{l})$ & $(1-1)$ & $\mathrm{SSl}$ & $\mathrm{MSl}$ & $\sigma^{2}+\sigma^{2} \mathrm{~g}$ \\
Check $(\mathrm{c})$ & $(\mathrm{c}-1)$ & $\mathrm{SSc}$ & $\mathrm{MSc}$ & $\sigma^{2}+\mathrm{r}^{2} \mathrm{c}$ \\
Line vs check & 1 & $\mathrm{SSlxc}$ & $\mathrm{MSlxc}$ & \\
Error & $(\mathrm{c}-1)(\mathrm{r}-1)$ & $\mathrm{SSe}$ & $\mathrm{MSe}$ & $\sigma^{2}$ \\
\hline Total & $(\mathrm{rc}+\mathrm{l})-1$ & $\mathrm{SSt}$ & & \\
\hline
\end{tabular}

The calculation of variance components is obtained based on the following formula:

$\begin{array}{ll}\sigma^{2} e & =\frac{\mathrm{MSe}}{\mathrm{r}} \\ \sigma^{2} g & =\frac{(\mathrm{MSm}-\mathrm{MSe})}{\mathrm{r}} \\ \sigma^{2} p & =\sigma^{2} g+\sigma^{2} e\end{array}$




$$
\begin{aligned}
& \begin{array}{lr}
\text { hbs } & =\frac{\sigma 2 \mathrm{~g}}{\sigma 2 \mathrm{p}} \times 100 \% \\
\mathrm{G}(\%) & =k \frac{\sigma 2 \mathrm{p}}{x} \times 100 \%
\end{array} \\
& \mathrm{GCV}(\%)=\frac{\sqrt{\sigma^{2} \mathrm{~g}}}{\mathrm{x}} \times 100 \% \\
& \operatorname{PCV}(\%)=\frac{\sqrt{\sigma^{2} \mathrm{p}}}{\mathrm{x}} \times 100 \%
\end{aligned}
$$

where:

$h b s=$ board sense heritability; $\sigma^{2} \mathrm{e}=$ environment variance; $\sigma^{2} p=$ phenotipe variance; $\sigma^{2} \mathrm{~g}=$ genetic variance; $x=$ grand mean, $\mathrm{GA}=$ expected genetic advance, $\mathrm{k}=$ standardized selection differential constant (2.06) at $5 \%$ selection intensity. GA as percent mean was categorized as low (0-10\%), moderate $(10-20 \%)$ and high $(\geq 20 \%)$. The Heritability was categorized as low (0-30\%), moderate $(30-60 \%)$ and high ( $60 \%$ and above) as followed by Abebe et al. (2017).

Wide or narrow the value of the genetic variance of a character was determined by genetic variance as described below:

$$
\sigma_{\sigma^{2} g}=\sqrt{\frac{2}{r^{2}}\left[\frac{K T l^{2}}{\left(\mathrm{db}_{1}+2\right)}+\frac{\mathrm{KTe}^{2}}{\left(\mathrm{db}_{\mathrm{e}}+2\right)}\right.}
$$

\section{Where:}

$\sigma \sigma^{2} g=$ standard deviation of genetic variance; $\mathrm{MSl}=$ mean square of lines; $\mathrm{MSe}=$ mean square of the environment; $r=$ replication; $\mathrm{dfl}=$ degree of freedom of lines; dfe $=$ degree of freedom of environment. If $\sigma^{2} \mathrm{~g}$ $>2 \sigma \sigma^{2} g$ : wide genetic variance, $\sigma g_{2}<2 \sigma \sigma 2 g$ : narrow genetic variance.

\section{Result and Discussion}

Table 1. showed the mean square and, coefficients of variation $(\mathrm{CV})$ of five characters of the rice lines. The analysis of variance of genotypes, lines, lines vs. checks, and blocks displayed significant differences ( $\mathrm{p}$ $<0.05)$ in their mean performance on several productive tillers. The lines vs. check also affected the flowering age and harvest time while the block has a significant effect of all characters. The check varieties gave significantly effect on yield. This shows that between genotypes, lines, and checks and blocks, there is a high diversity resulting in different appearance of the characters during the present study. The coefficients of variation $(\mathrm{CV})$ were low except for yield.

Performance of the check varieties in the experiment was showed in Table 2. Based on the result of the Tukey test at $5 \%$ level, it is known that there is no difference between check varieties on plant height, a number of productive tillers, and day to maturity. Inpago 8 has a longer flowering age than that of other varieties. Inpago 6 and Situbagendit have the shortest life duration compared to others. Bahtiar et al. (2013) showed that Situpatenggang was the shortest growth duration, followed by Situbagendit and Inpago 6. Situbagendit has the highest yield among other varieties with a yield of

\begin{tabular}{|c|c|c|c|c|c|}
\hline Character & $\begin{array}{c}\text { Inpago } \\
6 \\
\end{array}$ & $\begin{array}{c}\text { Inpago } \\
8 \\
\end{array}$ & Limboto & $\begin{array}{c}\text { Situ } \\
\text { patenggang }\end{array}$ & $\begin{array}{c}\text { Situ } \\
\text { bagendit }\end{array}$ \\
\hline $\begin{array}{l}\text { Plant } \\
\text { height }\end{array}$ & $94.2 \mathrm{a}$ & $95.3 \mathrm{a}$ & $86.3 \mathrm{a}$ & $94.3 \mathrm{a}$ & $77.1 \mathrm{a}$ \\
\hline $\begin{array}{l}\text { Number of } \\
\text { productive } \\
\text { tiller }\end{array}$ & $11.2 \mathrm{a}$ & $10.9 \mathrm{a}$ & $11.6 \mathrm{a}$ & $10.7 \mathrm{a}$ & $14.4 \mathrm{a}$ \\
\hline $\begin{array}{l}\text { Days to } \\
\text { flowering }\end{array}$ & $100.6 \mathrm{~b}$ & $111.2 \mathrm{a}$ & $103.4 \mathrm{ab}$ & $105.4 \mathrm{ab}$ & $100.6 \mathrm{~b}$ \\
\hline $\begin{array}{l}\text { Days to } \\
\text { maturity }\end{array}$ & $125.0 \mathrm{a}$ & $131.2 \mathrm{a}$ & $124.8 \mathrm{a}$ & $124.8 \mathrm{a}$ & $125.4 \mathrm{a}$ \\
\hline Yield & $3.18 \mathrm{ab}$ & $2.45 \mathrm{~b}$ & $2.3 \mathrm{~b}$ & $2.3 \mathrm{~b}$ & $4.57 \mathrm{a}$ \\
\hline
\end{tabular}
$4.57 \mathrm{t} / \mathrm{ha}$.

Table 2 Mean square of rice lines characters

\begin{tabular}{lcccccc}
\hline Character & Genotype & Line & Check & $\begin{array}{c}\text { Line } \\
\text { vs } \\
\text { check }\end{array}$ & Block & CV \\
\hline $\begin{array}{l}\text { Plant } \\
\text { height }\end{array}$ & 197.1 & 192.9 & 306.0 & $588.6^{*}$ & $1044^{*}$ & 11.9 \\
$\begin{array}{l}\text { Number of } \\
\text { productive }\end{array}$ & $24.6^{*}$ & $24.5^{*}$ & 11.5 & $89.6^{*}$ & $47.3^{*}$ & 23.9 \\
tiller & & & & & & \\
$\begin{array}{l}\text { Days to } \\
\text { flowering }\end{array}$ & 30.6 & 28.7 & 53.6 & $330.5^{*}$ & $321.5^{*}$ & 5.3 \\
$\begin{array}{l}\text { Days to } \\
\text { maturity }\end{array}$ & 22.7 & 21.1 & 32.4 & $289.7^{*}$ & $284.4^{*}$ & 2.5 \\
$\begin{array}{l}\text { Yield } \\
\text { * Significantly different at } 5 \%\end{array}$ & 1.9 & $4.1^{*}$ & 0.3 & $5.4^{*}$ & 32.8 \\
\hline
\end{tabular}

Table 3 Performance of rice check varieties

The result of estimation of genotype variance, phenotype variance, environment variance, heritability, and genetic gain was presented in Table 3. Heritability ranged from $0.1-0.6 \%$. Heritability would determine whether the difference in the appearance of a character is caused by genetic or environmental factors and by the interaction between genetic-environment factors. The expected heritability value of a character needs to be known to determine the character is more influenced by genetic or environmental factors. This high heritability value means that genetic factors make an essential contribution in the next selection process because selection in high heritability populations will be more effective than those with low heritability (Sabu et al. 
2009). The number of productive tillers has a high heritability value with a value of 0.57 . High heritability value can provide information that the selection is effectively performed on the character. The broad genetic diversity criteria and percentage of genetic progress were found on several productive tillers. This finding was in line with research by Perera et al. (2014). Improving a character through plant breeding programs requires information on genetic diversity, heritability, and genetic advance (GA). GA is an indicator of the progress that can be expected as a result of selection on a population (Alam et al. 2014). High genetic advance coupled with high heritability estimates offers the most suitable condition for selection (Ogunniyan and Olakojo 2014), and in this experiment, is found in a number of the productive tillers. The same result was reported by Seyoum et al. (2012) in upland rice genotypes.

Phenotypic coefficient of variation (PCV) also recorded for a number of productive tillers indicate the existence of a broad spectrum of variability for this trait and offer more significant opportunities for the desired trait through phenotypic selection (Anis et al. 2013). The PCV for a number of productive tiller and yield was higher than the genetic coefficient of variability (GCV). This significant differences between GCV and PCV, indicating that they all interacted with the environment to some extent or strong environmental influences on the expression of characters (Islam et al. 2015 ). The lowest GCV and PCV were observed on days to flowering. Slight differences indicated minimum environmental influence (Seyoum et al. 2012).

A total of $10 \%$ lines with the highest adjusted values of yield and other characters of each line were presented in Table 4. Based on the value of LSI (Least Significant Increase), there were three lines: B11787E-MR-2-9-7, B13134-4-MR-1-KA-1-BTGB-35-3, and B15378-TGB-59 that significantly higher than the best check Situbagendit. According to Petersen (1994), the LSI test is sufficient for comparing the results between strains and their check varieties in augmented experimental design. However, all lines performed higher yields from Situpatenggang. The plant height and day to the flowering of the tested lines were lower than the check varieties then it can be suggested that the lines will be not easy to lodge as a severe problem in rice and can be influenced by cultivar (Bridgemohan and Bridgemohan 2014) or nitrogen application (Hassan et al. 2016).
Table 4 Adjusted characters performance of upland rice lines and check varieties

\begin{tabular}{|c|c|c|c|c|c|c|c|}
\hline No & $\begin{array}{l}\text { Exp. } \\
\text { No. }\end{array}$ & Genotype & $\mathbf{Y}$ & PH & NPT & DF & HT \\
\hline 1 & 94 & B11787E-MR-2-9-7 & 7.6 & 84.9 & 9.0 & 111.3 & 136.5 \\
\hline 2 & 75 & $\begin{array}{l}\text { B13134-4-MR-1- } \\
\text { KA-1-B-TGB-35-3 }\end{array}$ & 7.2 & 114.7 & 13.7 & 107.7 & 131.7 \\
\hline 3 & 143 & B15378-TGB-59 & 7.2 & 107.3 & 16.1 & 108.7 & 127.9 \\
\hline 4 & 202 & $\begin{array}{l}\text { B15341-1B-TB-2 } \\
\text { B1 1957-SR*-2-3-2- }\end{array}$ & 6.6 & 116.1 & 20.3 & 105.3 & 126.3 \\
\hline 5 & 101 & $\begin{array}{l}\text { 18-2-SI-2-MR-2- } \\
\text { PN-2-1 }\end{array}$ & 6.5 & 73.6 & 9.0 & 116.3 & 131.5 \\
\hline 6 & 123 & B $15175 \mathrm{C}-\mathrm{TGB}-10$ & 6.4 & 80.6 & 11.0 & 95.3 & 122.5 \\
\hline 7 & 145 & B15379-TGB-4 & 6.4 & 90.3 & 15.1 & 113.7 & 127.9 \\
\hline 8 & 198 & B15119C-TB-5 & 6.4 & 108.4 & 20.3 & 110.3 & 121.3 \\
\hline 9 & 196 & B15119C-TB-6 & 6.4 & 89.4 & 12.3 & 110.3 & 123.3 \\
\hline 10 & 159 & $\begin{array}{l}\text { B14958-MR-1 1-25- } \\
4-1\end{array}$ & 6.2 & 121.0 & 14.1 & 113.7 & 136.9 \\
\hline 11 & 65 & B14981B-TGB-40-1 & 6.1 & 81.0 & 16.7 & 110.7 & 132.7 \\
\hline 12 & 201 & B15119C-TB-18 & 5.8 & 113.9 & 8.3 & 105.3 & 134.3 \\
\hline 13 & 138 & B15302B-TGB-38 & 5.7 & 102.6 & 7.0 & 104.3 & 126.5 \\
\hline 14 & 144 & B15379-TGB-3 & 5.7 & 94.0 & 26.1 & 108.7 & 127.9 \\
\hline 15 & 73 & B15033B-TGB-79-2 & 5.5 & 99.0 & 10.7 & 105.7 & 126.7 \\
\hline 16 & 42 & B14957-MR-2-3-2 & 5.4 & 98.4 & 8.9 & 107.2 & 125.6 \\
\hline 17 & 200 & B15119C-TB-13 & 5.1 & 87.4 & 10.3 & 105.3 & 131.3 \\
\hline 18 & 117 & B15143C-TGB-37 & 5.0 & 94.9 & 8.0 & 111.3 & 129.5 \\
\hline 19 & 173 & B 15340 -2B-TB-23 & 5.0 & 88.3 & 10.1 & 92.7 & 130.9 \\
\hline 20 & 191 & B15344B-TB-31 & 5.0 & 94.4 & 10.3 & 110.3 & 131.3 \\
\hline 21 & 62 & B14981B-TGB-27-2 & 4.9 & 89.0 & 14.7 & 113.7 & 134.7 \\
\hline 22 & 86 & $\begin{array}{l}\text { B13131-7-MR-1- } \\
\text { KA-1-4-B-TGB-10 } \\
\text { Check + LSI }\end{array}$ & 4.9 & 103.0 & 9.7 & 101.7 & 133.7 \\
\hline $\begin{array}{c}\text { Cek } \\
\text { A }\end{array}$ & & Inpago 6+LSI & 5.8 & 114.9 & 19.5 & 115.1 & 134.9 \\
\hline $\begin{array}{c}\text { Cek } \\
\text { B }\end{array}$ & & Inpago $8+\mathrm{LSI}$ & 5.0 & 122.8 & 19.2 & 122.7 & 140.2 \\
\hline $\begin{array}{c}\text { Cek } \\
\text { C }\end{array}$ & & Limboto+LSI & 5.4 & 105.6 & 19.9 & 117.9 & 138.9 \\
\hline $\begin{array}{c}\text { Cek } \\
\text { D }\end{array}$ & & Situpatenggang+LSI & 4.8 & 118.0 & 18.9 & 119.8 & 134.7 \\
\hline $\begin{array}{c}\text { Cek } \\
\text { E }\end{array}$ & & Situbagendit+LSI & 7.1 & 122.8 & 22.7 & 115.1 & 135.3 \\
\hline
\end{tabular}

*PH $=$ plant height, NPT $=$ number of productive tiller, $\mathrm{DF}=$ days to flowering, $\mathrm{HT}=$ harvest time, $\mathrm{Y}=$ yield. LSI for $\mathrm{PH}=28.5, \mathrm{NPT}=8.27, \mathrm{DF}=14.5, \mathrm{HT}=9.9, \mathrm{Y}=2.57$

\section{Conclusion}

1. The number of productive tillers can be utilized as selection criteria because of wide genetic variation, heritability value, and high genetic progress for increasing yield in upland ecology.

2. There were identified three lines with a higher yield than the best check varieties Situbagendit. The three lines were B11787EMR-2-9-7, B13134-4-MR-1-KA-1-B-TGB35-3, and B15378-TGB-59.

\section{Acknowledgment}

We would like to appreciate Mr. Supartopo for his hard work-contribution during this experiment. 


\section{References}

Abdurrachman, A., A. Dariah dan A. Mulyani. 2008. Strategi dan teknologi pengelolaan lahan kering mendukung pengadaan pangan nasional. J. Litbang Pert. 27(2): 43-49.

Abebe, T., S. Alamerew and L. Tulu. 2017. Genetic variability, heritability and genetic advance for yield and its related traits in rainfed lowland rice (Oryza sativa L.) Genotypes at Fogera and Pawe, Ethiopia. Adv. Crop. Sci. Tech. 5(2): 1-8.

Alam, M.S., L. Hassan., M.M. Islam, S.N. Begum and S.N. Islam. 2014. Evaluation of habitual rice (Oryza sativa L.) landraces of Bangladesh through different genetic parameters. Int. J. of Innov. and Sci. Res. 11(2): 494-502.

Anis, G., G.E.L. Sabagh, A. Ghareb and EL-Rewainy. 2016. Evaluation of promising lines in rice (Oryza sativa L.) to agronomic and genetic performance under Egyptian conditions. Int. J. of Agron. and Agric. Res. 8(3): 52-57.

Bakhtiar, Hasanuddin dan H. Taufan. 2013. Identifikasi beberapa varietas unggul padi gogo di aceh besar. J. Agrista 7(2): 49-54.

[BPS] Badan Pusat Statistik. 2013. Luas panen, produktivitas dan produksi padi nasional. http://www.bps.go.id/tnm_pgn.php? [Februari 2017 ].

Bridgemohan, P. and R.S.H. Bridgemohan. 2014. Evaluation of anti-lodging plant growth regulators on the growth and development of rice (Oryza sativa). Journal of Cereals and Oilseeds 5(3):12-16.

Hassan, F.O., A.G. Elwi, G.N. Waked and Y.F. Tork. 2016. Improvement of lodging resistance of Sakha 102 rice cultivar under different rates of nitrogen fertilizer. Int. J. of Plant Breed. and Genet. 3(4): 200-210.

Herawati, R., B.S. Purwoko and S.D. Iswari. 2010. Characterization of doubled haploid derived from anther culture for new tiype upland rice. J. Agron. Ind. 38(2):81-87.

Islam, M.A., S.A. Raffi, M.A. Hossain and A.K. Hasan. 2015. Analysis of genetic variability, heritability and genetic advance for yield and yield associated traits in some promising advanced lines of rice. Progressive Agric. 26:2631.

Johnson, H.W., H.F. Robinson and R.E. Comstock. 1955. Estimates of genetic and environmental variability in soybean. Agron.J., 47: 314-318.
Ogunniyan, D.J. and S.A. Olakojo. 2014. Genetic variation, heritability, genetic advance and agronomic character association of yellow elite inbred lines of maize (Zea mays L.). Nigerian J. of Genet. 28: 24-28.

Perera, U.I.P., D. Ratnasekera, S.G.J.N. Senanayake and de Z. D.S. Abeysiriwardena. 2014. Genetic parameters and correlations of yield attributing characteristics of weedy rice in Sri Lanka. J. Natn. Sci. Foundation Sri Lanka 42(4): 299-306.

Petersen, R.G. 1994. Agricultural Field Experiment: Design and Analysis. Marcel Dekker, Inc. New York. 409 pp.

Sabu, K.K, M.Z. Abdullah, L.S. Lim and R. Wickneswari. 2009. Analysis of heritability and genetic variability of agronomically important traits in Oryza sativa L. x O. rufipogon Cross. Agronomy Res. 7:97-102.

Saleem, M.Y., J.I. Mirza and M.A. Haq. 2008. Heritability, genetic advance, and heterosis in line $\mathrm{x}$ tester crosses of Basmati rice. Journal Agricultural Research 46: 15-26.

Sasmita, P. 2007. Aplikasi tenik kultur antera pada pemuliaan tanaman padi. Prosiding: Apresiasi Hasil Penelitian Padi. Balai Besar Penelitian Tanaman Padi. Hlm:595-609.

Seyoum, M., S. Alamerew and K. Bantte. 2012. Genetic variability, heritability, correlation coefficient and path analysis for yield and yield related traits in upland rice (Oryza sativa L.). J. of Plant Sci. 7(1): 13-22.

Singh, R.K. and B.D. Chaudhary. 1979. Biometrical methods in quantitative genetic analysis. Kalyani Publishers, Ludhiana. 318. 